\title{
Anti-predator defenses in western North Atlantic sponges with evidence of enhanced defense through interactions between spicules and chemicals
}

\author{
Malcolm S. Hill ${ }^{1,2, *}$, Nora A. Lopez ${ }^{1}$, Kimberly A. Young ${ }^{1}$ \\ ${ }^{1}$ Biology Department, Fairfield University, Fairfield, Connecticut, 06824, USA \\ ${ }^{2}$ Present address: Department of Biology, Gottwald Science Center, University of Richmond, Richmond, Virginia 23173, USA
}

\begin{abstract}
We examined anti-predator defenses in 4 species of temperate sponge from Long Island Sound using a common hermit crab (Pagurus longicarpus) as predator in pair-wise feeding preference tests comparing palatable control versus treatment food. Only Haliclona loosanoffi failed to deter hermit crab feeding. The other 3 species reduced $P$. longicarpus feeding rates, although the mechanism of deterrence differed for each sponge. Spicules and crude extracts interacted to enhance deterrence in experiments involving Microciona prolifera because combining spicules and crude extract in artificial food significantly reduced crab feeding rates by $53 \%$. When added to artificial food in isolation, neither spicules nor crude extract from $M$. prolifera significantly altered feeding rates of the crabs. Crude extracts, spicules and a combination of spicules and crude extract isolated from Halichondria bowerbanki all significantly reduced crab feeding rates compared to consumption of control food. Structural materials were significantly deterrent in feeding trials involving Cliona celata (32\% reduction in feeding), but artificial food containing either crude extract or crude extract plus spicules was significantly preferred over control food. Both $H$. bowerbanki and C. celata produce spicules that average $\geq 285 \mu \mathrm{m}$ in length, which is above the threshold length that has been hypothesized to deter predators. The data involving $M$. prolifera, H. bowerbanki, and C. celata indicate that temperate sponges use chemical and structural defenses against potential predators, and that structural and chemical defenses interact in $M$. prolifera. Results of this and other studies indicate that it may be fruitful to look for additive and synergistic defenses in other sponge species, especially those found to be chemically undefended when compounds were tested in isolation.
\end{abstract}

KEY WORDS: Defensive synergism $\cdot$ Porifera $\cdot$ Morphological defense $\cdot$ Temperate habitats

\section{INTRODUCTION}

Of the 212 species of West Indian fish assessed by Randall \& Hartman (1968), $10 \%$ had sponge remains in their stomachs, but only 11 species were characterized as intentional sponge-feeders. Given the relatively small fraction of spongivorous fish, it was concluded that poriferan distributions in the West Indian region of the Caribbean were unlikely to be influenced by fish predation. Indeed, Randall \& Hartman (1968) dismissed a report by Bakus (1964) that indicated that fish predation influenced sponge distributions in marine systems.
The view that spongivores have a small influence on sponge ecology contrasts with our current understanding of the effects predation has on sponge populations and benthic marine communities in general (e.g. Pawlik 1998). It has been demonstrated by several authors that differential predation pressure along complex environmental gradients like coral reefs can have major effects on the distribution of sponges. For example, Wulff (2000) compared sponge communities growing on mangrove prop roots located in habitats that differed in the presence and abundance of spongefeeding fish, and found substantial differences in sponge diversity, which was attributed to the effects of 
sponge predators. Wulff (1995) also found that the starfish Oreaster reticulatus restricts sponges from seagrass beds that lack starfish-specific defenses. Large vertebrate predators, such as the hawksbill turtle, have been shown to reduce the abundance of sponge populations on Caribbean reefs (Leon \& Bjorndal 2002). Dunlap \& Pawlik (1996) used an underwater video observatory to determine whether Caribbean reef fish can restrict the distribution of sponges normally found in mangrove habitats. They transplanted 8 species of sponge (4 species from the reef and 4 from mangroves) into a common area on Conch Reef, Florida, and remotely recorded over 35000 bites on the sponges. Over $95 \%$ of the bites were taken from the sponge species found in mangroves and not on sponges that reside on the reef (Dunlap \& Pawlik 1996). Further support for the hypothesis that spongivores limit the distribution of some sponges comes from the morphologically variable sponge Cliona varians. C. varians appears to have predator-resistant forms (C. varians forma incrustans and $C$. varians forma rigida) that are found on the reef, and a predator-susceptible form $(C$. varians forma varians) that is restricted to predatorfree, shallow-water habitats (Pawlik 1998, Hill 1999, Hill \& Hill 2002). Finally, spongivorous fish have the potential to affect community structure and function because consumption of sponges reduces poriferan competitive abilities, which indirectly benefits coral populations (Hill 1998). These and other studies (e.g. Dayton et al. 1974) clearly demonstrate that spongivores influence the abundance and distribution of individual species and can help shape features of benthic communities.

While the ecological significance of spongivores may have been underestimated by Randall \& Hartman (1968), support for their hypothesis that sponges are avoided by predators due to a suite of defensive traits has come from a number of studies. There has been intense exploration of sponge anti-predator defenses over the past decade, and scientists have considered each of the 3 characteristics (i.e. spicules, noxious chemical substances and collagenous skeletal material) proposed by Randall \& Hartman (1968). Naturalproduct chemists and chemical ecologists have increased our understanding of the role chemical substances play in anti-predator defenses (Paul 1992, Pawlik 1993, McClintock \& Baker 2001). There is a consensus among researchers in this field that production of chemical defenses is a major reason for the avoidance of sponges by many potential predators since it is well documented that sponges produce secondary metabolites that have anti-feeding properties (e.g. McClintock 1987, Pennings et al. 1994, Pawlik et al. 1995, Pawlik 1997, Becerro et al. 1998, 2003). Indeed, nearly $70 \%$ of the 71 Caribbean sponge spe- cies examined by Pawlik et al. (1995) were found to deter predation by the fish Thallasoma bifasciatum via chemical means.

The role sponge skeletal features play in defense has received less attention than chemical defenses, and experiments designed to test whether structural features serve a defensive purpose have produced contrasting results. Correlative evidence that structural defenses are important include observations that spongivorous fish will rapidly begin to feed on recently exposed portions of the choanoderm only after the thick pinacoderm is removed (e.g. Targett \& Schmahl 1984, Hill 1999). Hill \& Hill (2002) proposed that the cortex of Cliona varians provides a physical defense against predators, and demonstrated experimentally that simulated attacks induced spicule production resulting in higher spicule density in areas where cuts had been made. Whether the observed changes in spicule concentration result in increased defense (rather than a generalized healing response; Duckworth 2003) remains to be tested directly, but several studies have used feeding preference tests to examine effectiveness of structural defenses. Uriz et al. (1996) found evidence for physical defenses in the Mediterranean Crambe crambe, where intact sponge skeletons were shown to reduce feeding by a common sea urchin. In contrast, spiculated skeletons devoid of organic compounds have been found to be ineffective at deterring predators for 2 species of reef sponge and 4 species commonly found in mangrove habitats (Chanas \& Pawlik 1996, Waddell \& Pawlik 2000a,b). In a more recent study, Burns \& Ilan (2003) found that isolated spicules served a defensive role in approximately $40 \%$ of sponges examined during feeding trials with Red Sea and Caribbean wrasses. They also found a positive correlation between spicule length and deterrence effectiveness. Chanas \& Pawlik (1995, 1996), however, found that spicules, regardless of type or size, from 8 species were ineffective at reducing rates of consumption by fish in laboratory and field assays, but became deterrent when nutritional quality of the food, in terms of protein content, was below a particular threshold. Hermit crabs and sea stars were also undeterred by the presence of isolated spicules (Waddell \& Pawlik 2000a,b).

These discrepancies indicate that additional work is needed to fully understand sponge defenses, and a potentially fruitful area of research is to look for interactions between spicules and crude extracts. Burns \& Ilan (2003) examined how wrasse predation rates were affected by spicules and crude extract presented in combination. Their data suggest that a combination of spicules and crude extract can reduce feeding rates below levels found when the 2 materials are presented separately to potential predators. The combinatorial 
approach (i.e. providing both structural and chemical material to potential predators) has been used effectively in studies focused on anti-herbivore defenses in algae and plants (Hay et al. 1994, Pennings et al. 1998). Indeed, important synergistic interactions between structural and chemical defenses have been identified in this manner (Hay et al. 1994).

It is important to note that a great deal of our understanding of sponge anti-predator defenses comes from tropical ecosystems. Much less is known about predator-sponge dynamics in higher latitude marine habitats, despite evidence that sponges experience high rates of predation in these regions (e.g. Dayton et al. 1974, Bloom 1975, 1976, 1981, Guida 1976, Thompson \& Brown 1984). There are examples of chemical and structural anti-predator defenses in polar and temperate sponges (McClintock 1987, Turon et al. 1996, 1998, Uriz et al. 1996, Burns \& Ilan 2003, Furrow et al. 2003), and contrary to expectations there appears to be no diminution of defenses with increasing latitude (Amsler et al. 2000). Indeed, Becerro et al. (2003) compared Indo-Pacific and Mediterranean sponges and found that tropical and temperate species had comparable defenses that were 'equally strong' and 'equally effective'. To fully understand the ecological and evolutionary significance of predator-sponge interactions, ecosystems at higher latitudes deserve greater attention.

Given that (1) spongivores affect ecological and evolutionary aspects of sponge biology; (2) there is limited evidence of diminution of anti-predator defenses in sponges as one moves towards the poles; and (3) relatively little is known of potential interactions between structural and chemical qualities of particular sponge species, much additional work remains to fully understand the nature of sponge anti-predator defenses in the variety of habitats that sponges occupy. Here, we tested for the presence of anti-predator defenses in 4 temperate species of sponge from Long Island Sound. We used a series of feeding trials to assess deterrent capabilities of structural and chemical features from each species, both in isolation and combination.

\section{MATERIALS AND METHODS}

Collection sites and organisms. Microciona prolifera, Haliclona loosanoffi, Halichondria bowerbanki, and Cliona celata were collected at sites on the NW shore of Long Island Sound (between $41^{\circ} 16^{\prime} \mathrm{N}, 72^{\circ} 57^{\prime} \mathrm{W}$ and $40^{\circ} 50^{\prime} \mathrm{N}, 73^{\circ} 55^{\prime} \mathrm{W}$ ) from late June through early September 2002. These species were chosen because they are among the most common members of sponge communities along the New England shore. All collections were done at low tide below the mean low-waterline.
Sponges were growing on rocks in stands of algae, and were removed by hand and placed in 11 containers for transport to the lab.

Pagurus longicarpus hermit crabs were chosen as the predator for these experiments for several reasons. First, the crabs are extremely abundant in Long Island Sound (authors' pers. obs.). Second, their distribution overlaps with that of all of the sponges used in this study so there are many opportunities for interaction. We frequently encountered juvenile and adult crabs crawling on sponges, and often observed crabs picking at sponge material (although we could not confirm that sponges had been consumed). Third, P. longicarpus is an omnivorous scavenger, and thus represents a potential generalist predator that might include sponge in its diet if sponges were palatable. Various temperate crab species consume sponge (e.g. sponges represent 6 to $22 \%$ of the diet of the Newfoundland snow crab Chionoecetes opilio; Wieczorek \& Hooper 1995) but the precise composition of P. longicarpus' diet is unknown.

Hermit crabs were collected at Anchor Beach in Milford, Connecticut $\left(41^{\circ} 16^{\prime} \mathrm{N}, 72^{\circ} 57^{\prime} \mathrm{W}\right)$, and Jennings Beach in Fairfield, Connecticut $\left(41^{\circ} 08^{\prime} \mathrm{N}, 73^{\circ} 16^{\prime} \mathrm{W}\right)$, during the summer of 2002 . Hermit crabs were placed in $10 \mathrm{~cm}$ deep trays $(1.2 \times 0.6 \mathrm{~m})$ that received recirculating seawater collected from Long Island Sound. Water was replaced at least once weekly. Pieces of frozen squid were placed in the trays to keep crabs satiated until they were used in experiments.

Extraction of chemicals and spicules. Sponges were returned to the lab and processed within $4 \mathrm{~h}$ of collection. Each of the 4 sponge species was subjected to the same chemical and spicule extraction procedures. Pawlik and colleagues have established clear experimental guidelines for the extraction of sponge metabolites for feeding assays (e.g. Pawlik et al. 1995, Waddell \& Pawlik 2000a), and we employed their protocol throughout. The goal of the procedure was to obtain a crude extract of secondary metabolites and incorporate them in artificial food at natural volumetric concentrations.

Any non-sponge material (e.g. invertebrates and algae) was removed prior to processing, and the sponges were rinsed in clean seawater after having any epibionts removed. Sponge volume was estimated via displacement, whereby the sponge was cut into small pieces that were placed in a graduated cylinder containing seawater. After sponge volume had been measured, wet weights were quickly determined. Once the sponges had been weighed, two $1 \mathrm{~h}$ extractions were performed in methanol followed by a $2 \mathrm{~h}$ extraction in a 1:1 dichlormethane: methanol solution. All extractions were performed at $4^{\circ} \mathrm{C}$. Solvent volume applied to each sponge was equal to the estimated 
sponge volume. Each extraction was sequentially vacuum-filtered through diatomaceous earth. For each species, 5 individual sponges were used, and we combined the filtered solutions obtained from each individual of a given species at this step. By combining material from the 5 different individuals, we averaged the effects of any phenotypic variability that may have naturally existed among individuals at the onset of the experiment, and, as in Becerro et al. (2003), obtained the mean percent yield concentration for use in feeding assays. At this point, solvent was evaporated from solution using a rotary evaporator at $<45^{\circ} \mathrm{C}$. The resulting crude extract was stored in a sealed container at $4^{\circ} \mathrm{C}$ until it was added to food, which typically occurred within $24 \mathrm{~h}$.

After the final extraction, nitric acid was added to sponge tissues following standard procedures (KellyBorges \& Pomponi 1992) to isolate skeletal components. Once all tissue had dissolved, spicules were concentrated by centrifugation, and washed 3 times with distilled water. Cliona celata incorporates sand in its tissues, and some of this material remained after the tissue was cleaned with nitric acid. Sand was added to our artificial food along with spicules isolated from the sponge because predators would encounter this material if they consumed any sponge tissue. A final ethanol wash was performed, and after air-drying, the material was weighed. As with the chemical extracts, isolated spicules were combined for all 5 individuals of a given species to average natural variability in spicule concentration within species.

Feeding assays. We employed the experimental design of Hay et al. (1994) for our feeding assays, which is a conservative and effective method for looking for interactions (Hay 1996, Pennings 1996). Feeding tests consisted of placing an individual hermit crab in a chamber with a control food strip and a treatment food strip. Treatments contained spicules, crude extracts or a combination of spicules and crude extract. Thus, 3 different choice experiments were run for each of the 3 treatments. Differences between consumption rates on control and treatment food strips were then compared (see description of statistical methodology below).

Artificial food consisted of $50 \mathrm{mg}$ of TetraMin ${ }^{\circledR}$ flake fish food and $10 \mathrm{mg}$ of carrageenan per $\mathrm{ml}$ of solution. We used protein values reported in Chanas \& Pawlik (1995) and the manufacturer's minimum crude protein content values to arrive at the final protein content used in these experiments $\left(\sim 24 \mathrm{mg} \mathrm{ml}^{-1}\right)$. This resulted in protein concentrations that were in the mid-range of the values presented from tropical sponges (Pawlik et al. 1995) and slightly above the average of $20.7 \mathrm{mg}$ $\mathrm{ml}^{-1}$ (Chanas \& Pawlik 1996). Once these components had been combined in the appropriate volume of distilled water, the solution was heated in a microwave oven until it just boiled. After the liquid had cooled slightly, spicules, crude extract or combination of spicules and extract were added to treatment food at appropriate concentrations. Crude extract was resuspended in methanol before adding to the artificial food. As in Waddell \& Pawlik (2000a,b), our final volume took into account solvent that evaporated after its addition to the hot gel. Methanol was added to control food and spicule treatment in the same ratio as was used for the crude extract treatment. Treatment food strips had final concentrations of chemical and structural material that were based on the estimated volume of the sponges used in the extraction procedure. That is, the amount of extract or spicule material added to the artificial food was done so at natural, volumetrically appropriate levels.

Artificial food strips were formed by pouring hot food mixture on window screening positioned beneath a $2 \mathrm{~mm}$ thick plexiglass mold (Hay et al. 1994). Once the gel solidified, molds were removed and food coloring was poured on top of all strips and allowed to absorb to mimic natural coloration of the experimental sponge and to remove any differences in appearance between control and treatment food. Replicates consisting of artificial food and window screening were cut so that each artificial food replicate covered exactly 36 squares of window screening. We distinguished among treatments by cutting representative patterns in excess screening of each square.

Assays were run in feeding arenas $\left(280 \mathrm{ml}\right.$ ZipLock $^{\circledR}$ containers) placed in a re-circulating seawater system. Individual arenas had multiple $8 \mathrm{~mm}$ diameter holes along the sides that allowed for water exchange but restricted crabs to the feeding arena. Sample sizes for each assay are shown in Fig. 1. Each feeding arena received 1 control food square, 1 treatment food square, and 1 predator of average size $(\sim 2 \mathrm{~cm}$ in shell width). Prior to initiating a feeding trial, hermit crabs were not fed for a period of $24 \mathrm{~h}$ to attempt to standardize feeding activity among the different replicate crabs. Crabs consumed artificial food at high rates in all experiments and appeared healthy throughout the study. Feeding trials were terminated after a maximum of $72 \mathrm{~h}$. Crab activity and overall behavior did not change during the experimental period, and all remaining crabs were released to their native habitat at the end of the study. Crabs were used only once in feeding trials, thus all preference tests involved experimentally naive crabs. Among replicate variation was successfully minimized by (1) standardizing hunger levels of crabs before they were placed in feeding chambers; (2) terminating feeding trials once $50 \%$ of the food had been removed from at least one of the strips (Hay et al. 1994); and (3) using crabs of approximately equal size. 

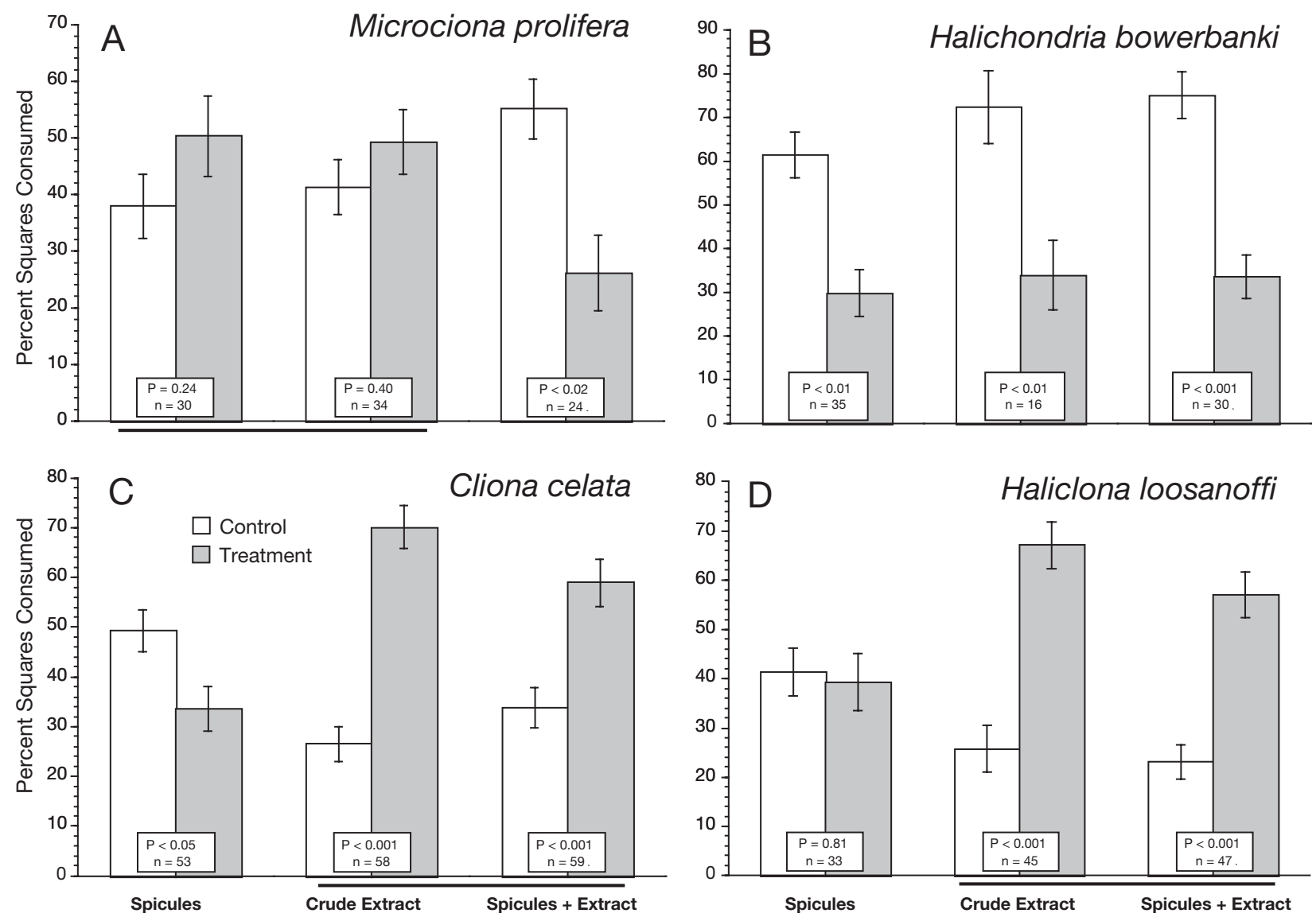

Fig. 1. Pagurus longicarpus. Effects of spicules (S) and crude extracts (C) from 4 species of temperate sponge on feeding rates of $P$. longicarpus. The number of squares consumed was converted to a percentage for ease of comparison in these figures, but statistics were performed on raw data; averages $( \pm \mathrm{SEM})$ are presented. p-values in each box are for the paired $t$-test or Wilcoxon's test that was performed in each feeding trial and $\mathrm{n}$ represents the number of replicates for that trial. One-way ANOVA or Kruskal-Wallis tests were employed to detect differences in crab preferences among the 3 feeding assays. Treatments connected by a line were not significantly different from one another at $\mathrm{p}<0.05$ based on Tukey's HSD or Student-Newman-Keuls tests. (A) Microciona prolifera. The treatment that included both spicules and crude extract produced a nearly $50 \%$ reduction in crab feeding rates. (B) Halichondria bowerbanki. Each treatment reduced crab feeding rates by more than half compared to controls. No statistically significant differences among treatments were detected. (C) Cliona celata. The spicule treatment deterred predation, but the crude extract and the spicule plus crude extract $(\mathrm{S}+\mathrm{C})$ treatments were preferred over control food. (D) Haliclona loosanoffi. The crude extract and spicule plus crude extract treatments were preferred over control food

Statistical analysis. Since each strip of artificial food covered exactly 36 squares of window screening when initially placed in the feeding arenas, determining amount of food consumed consisted of counting the number of squares present in treatment and control strips and subtracting these numbers from 36. Twotailed, paired-sample $t$-tests were used on normally distributed data to determine statistical differences between amount of treatment and control squares consumed (Zar 1984). Non-normally distributed data were analyzed using Wilcoxon's paired-sample test employed in JMPTM.

Using differences recorded in the paired-sample feeding assays, we performed ANOVA-type approaches to determine whether among-treatment dif- ferences existed in the effects of sponge characters on hermit crab feeding (Hay et al. 1994). Among-treatment differences were analyzed using 1-way ANOVA for normally distributed data with equal variances (Zar 1984). Tukey's HSD test was used to determine which treatments were significantly different. The KruskalWallis test was used if data were non-normally distributed or had unequal variances that could not be corrected. Multiple comparisons were performed using the non-parametric version of the Student-NewmanKeuls test (Zar 1984).

When differences obtained in the spicules plus crude extract experiment seemed to be larger than the experiments that included spicules or crude extract in isolation, we constructed a 'bootstrapped' dataset as de- 
scribed in Hay et al. (1994) to determine the extent of interactive effects. If the difference in the treatment was simply due to the sum of effects caused by spicule or crude extract, then summing random pairs of differences from these treatments should produce an average not significantly different than that observed in the combination treatment. If, however, significant differences were detected, that would indicate an interaction between structural and chemical properties of the sponge (e.g. Hay 1996). Significance of these differences was determined using the $t$-test.

\section{RESULTS}

Temperate sponges examined in this study utilized a diversity of structural and chemical strategies to deter predation. Evidence of an interaction between structural and chemical material was found in experiments conducted with Microciona prolifera. As can be seen in Fig. 1A, Pagurus longicarpus was significantly deterred from feeding (Wilcoxon's signed-rank test, $t=82.00$, $\mathrm{p}=0.015, \mathrm{n}=24$ ) when spicules and organic compounds extracted from $M$. prolifera were combined (i.e. the spicules plus crude extract [S $+\mathrm{C}]$ treatment). Feeding in the $\mathrm{S}+\mathrm{C}$ treatment was reduced by $>50 \%$ compared to the control. In contrast, $P$. longicarpus ate treatment food strips containing crude extracts (C) and treatment food containing spicules $(\mathrm{S})$ at the same rate they ate control food (Fig. 1A). Differences among S, C, and $\mathrm{S}+\mathrm{C}$ treatments were detected (Fig. 1A; ANOVA, $\left.F_{2,85}=4.56, \mathrm{p}<0.02\right)$. A multiple-comparisons test showed that $\mathrm{S}+\mathrm{C}$ was significantly different from both the $\mathrm{S}$ and $\mathrm{C}$ experiments. We tested whether differences observed in the $\mathrm{S}+\mathrm{C}$ preference tests were significantly different from summed, randomly paired differences recorded in the S and C treatments. Significant differences were found between these means ( $t$-test, 2-tailed, $\mathrm{p}<0.001$ ), which is consistent with the hypothesis that spicules and crude extract interact synergistically to defend $M$. prolifera.

Although Halichondria bowerbanki individuals do not reach large sizes at the sites where sponges were collected, they are locally abundant (authors' pers. obs.). H. bowerbanki was the only sponge that reduced feeding rates of Pagurus longicarpus in each of the 3 feeding trials (Fig. 1B). The $\mathrm{S}$ treatment cut feeding rates nearly in half compared to the control, and $\mathrm{C}$ and $\mathrm{S}+\mathrm{C}$ treatments were consumed at still lower rates compared to controls (Fig. 1B). ANOVA revealed no significant differences among the 3 treatments $\left(F_{2,78}=0.38, \mathrm{p}=0.686\right)$ indicating that $\mathrm{S}$ and $\mathrm{C}$ are equally effective at deterring predation by $P$. longicarpus, and that structural and chemical materials do not interact to reduce palatability.
Cliona celata and Haliclona loosanoffi produced similar feeding patterns in the $\mathrm{C}$ and $\mathrm{S}+\mathrm{C}$ treatments. For both species, hermit crabs significantly preferred artificial foods containing crude extracts regardless of whether spicules were included (Fig. 1C,D). The C treatment elevated feeding rates of C. celata by $269 \%$ and $H$. loosanoffi by $257 \%$ compared to controls, and feeding rates were elevated by $170 \%$ for C. celata and $247 \%$ for $H$. loosanoffi in the $\mathrm{S}+\mathrm{C}$ treatment (Fig. 1C,D). Differences among treatments for each species were not significant (Fig. 1C,D). However, the effect of structural elements on crab feeding differed for the 2 species. No difference in rates of consumption of control food or S treatment was detected in the $H$. loosanoffi feeding trial (Fig. 1D). In contrast, Pagurus longicarpus consumed control food at a significantly higher rate than the $\mathrm{S}$ treatment in experiments involving C. celata (Fig. 1C). Feeding trials involving C. celata's $\mathrm{S}$ treatment were significantly different from the $\mathrm{C}$ and $\mathrm{S}+\mathrm{C}$ feeding trials as indicated by the Kruskal-Wallis test $(\mathrm{p}<0.001)$.

\section{DISCUSSION}

Our goal in this study was to examine potential antipredator defenses from common sponges found in temperate waters of the western North Atlantic using Pagurus longicarpus as a model predator. Only 1 of the 4 species examined, Haliclona loosanoffi, did not deter predation either chemically or with spicules (Fig. 1D). Crabs significantly preferred the crude extract (C) and spicules plus crude extract $(\mathrm{S}+\mathrm{C})$ treatments over controls for $H$. loosanoffi. This sponge may belong to a chemically undefended genus since crude extracts from the Caribbean $H$. hogarthi have been found to be palatable (Pawlik et al. 1995, Waddell \& Pawlik 2000b). The mechanism employed to avoid predation by these sponges deserves greater attention because these sponges are common in many marine habitats and sponge predators often co-occur with this genus (e.g. Waddell \& Pawlik 2000b). The other 3 species examined in this study reduced feeding rates of $P$. longicarpus. The manner in which deterrence was accomplished differed for Microciona prolifera, $H$. bowerbanki, and Ciona celata, and each mechanism is discussed below.

\section{Deterrence in temperate sponges}

In experiments involving Microciona prolifera, hermit crabs were only deterred from eating in the $\mathrm{S}+\mathrm{C}$ treatment. Given that siliceous spicules are chemically inert, the observed interaction probably arises from a 
combination of mechanical and chemical means. Distinguishing whether this effect is additive or synergistic will require additional experiments that assay each component at multiple concentrations. The interaction observed in this study differs from the synergism identified in calcified seaweeds (Hay et al. 1994) because $\mathrm{CaCO}_{3}$ can act as a buffer, which may modify gut $\mathrm{pH}$ of potential predators, potentially facilitating the action of secondary metabolites. The most likely mechanical effect of siliceous spicules is abrasion or injury of feeding structures (e.g. mouth parts, lining of the digestive system), as has been observed in the gut of the hawksbill turtle (Meylan 1988). Sponge-derived chemicals may affect predator tissues if tougher, more resistant ectodermal layers of feeding organs are damaged by spicules. $M$. prolifera has a diverse assortment of mega- and microscleres, which have interesting morphological characteristics (Hartman 1958). Long subtylostyles typically have spiny heads, and smaller acanthosubtylostyles and acanthostyles are noticeably spined. We propose that spined spicules act as an abrasive passing through the gut of a potential predator and facilitate the action of chemical defenses.

Results from our experiments compare favorably to recent work done with Red Sea sponge Crella cyatophora (Burns \& Ilan 2003). In that study, the wrasse Thalassoma bifasciatum found spicule-laden artificial food palatable and artificial food containing crude extract unpalatable. However, when spicules and crude extract were combined, feeding rates of $T$. bifasciatum were reduced below that seen in the crude extract feeding trial. A similar pattern was observed for T. klunzingeri. If the interaction between structural and chemical components were additive, one would not necessarily expect the level of palatability in the $\mathrm{S}$ $+\mathrm{C}$ treatment to drop below that recorded in the C treatment, but additional experiments would be necessary to determine whether a synergistic interaction exists in C. cyatophora.

Examining interactions between chemical and structural materials may be important in feeding experiments because the focus on defensive characters (such as spicules or crude extract) in isolation may give an incomplete picture of anti-predator defenses in sponges. If, as in Microciona prolifera, neither crude extract nor spicules deter predation, one might draw the conclusion that the sponge is not defended, but our data indicate that this in not the case (Fig. 1A). Furthermore, chemical extracts found to be deterrent may become more deterrent when combined with structural materials as was seen in the bioassays employing Thalassoma bifasciatum and T. klunzingeri (Burns \& Ilan 2003). It is also possible that chemical extracts could nullify defensive properties of spicules as was observed in Cliona celata (Fig. 1C). Many of the pro- posed defenses may be species-specific, so additional predators must also be considered.

Hermit crabs were deterred by both spicules and crude extracts in experiments involving material isolated from Halichondria bowerbanki. Temperate and tropical members of the family Halichondriidae produce effective anti-predator defenses (e.g. Pawlik et al. 1995, Becerro et al. 2003, Burns et al. 2003). The $\mathrm{S}+\mathrm{C}$ treatment significantly deterred predation, but not at a significantly higher rate compared to either $\mathrm{S}$ or $\mathrm{C}$ treatments (Fig. 1B). Thus, there appears to be no interaction between these traits in deterring hermit crab feeding. Chanas \& Pawlik (1996) found that spicules became deterrent to Thalassoma bifasciatum when placed in food of low nutritional quality, but it is unlikely that deterrence observed in our $\mathrm{S}$ treatment arose for this reason. The artificial food used in this study contained more than 2 times the protein levels that induced feeding on spicule-laden food with the wrasse $T$. bifasciatum (Chanas \& Pawlik 1996) so our experiments likely represent a conservative test of the structural defense hypothesis with regard to protein content.

Inorganic material isolated from Cliona celata reduced feeding rates of hermit crabs compared to controls, while the $\mathrm{C}$ and $\mathrm{S}+\mathrm{C}$ treatments significantly stimulated feeding. One dilemma faced in these types of feeding trials involves the loss of 3-dimensional skeletal organization that occurs when spicules are dissolved from sponge tissue (Hill \& Hill 2002). As stated in Burns \& Ilan (2003), results from feeding assays where spicules are in a random orientation represent a conservative test of the structural defense hypothesis. Thus, we have greater confidence in our result indicating inorganic material is capable of serving a defensive purpose in C. celata. It is important to note, however, that this sponge incorporates sand in its tissue, and we added this material to our artificial food because any predator would encounter spicules and sand at the same concentrations we used in our artificial food. Whether reduced feeding rates were caused by spicules, sand or a combination of the two is not known. If sand serves a defensive purpose, then it represents a behavioral physical defense, since sand would have to be incorporated in tissue after it had been filtered from the water column or passed to different parts of the sponge from the substratum.

The crude extract obtained from Cliona celata appears to contain a compound that serves as a feeding stimulant for this hermit crab. It would appear that morphological defenses would be valuable for $C$. celata. One possible morphological defense is $C$. celata's cortex, which is most likely capable of withstanding attacks by a weak-clawed crab such as Pagurus longicarpus. Hill \& Hill (2002) proposed that the cortex represents a morphological defense, and pre- 
sented evidence indicating that the cortex was capable of protecting one of the morphs of the tropical sponge C. varians. Furthermore, some predators only consume sponge if choanoderm is exposed following removal of thicker, stiffer pinacoderm (e.g. Targett \& Schmahl 1984, Hill 1999).

An observation made during these feeding trials is that average spicule length was an adequate predictor of whether spicules would deter predation. Hartman (1958) reported spicule composition, and measured dimensions for each spicule type, for all 4 of the sponges used in the present study. We extracted spicule dimensions for Connecticut populations from his dataset and calculated average spicule lengths. The 2 species that demonstrated spicular defense, Halichondria bowerbanki and Cliona celata, had average spicule lengths of $285 \mu \mathrm{m}$ and $296 \mu \mathrm{m}$ respectively. Neither Microciona prolifera, with an average thick subtylostyle length of $247 \mu \mathrm{m}$ and thin substylostyle length of $189 \mu \mathrm{m}$, nor Haliclona loosanoffi, with an average spicule length of $107 \mu \mathrm{m}$, deterred feeding by hermit crabs. This supports a recent hypothesis that sponges with at least 1 spicule type $>250 \mu \mathrm{m}$ in length can effectively deter potential predators (Burns \& Ilan 2003). However, spicule sizes $<250 \mu \mathrm{m}$ might still serve a defensive purpose if they interact with chemical constituents of the sponge as was seen in M. prolifera.

\section{Do generalized defenses exist in sponges?}

The mechanisms that deterred hermit crab feeding in this study differed for each of the 3 sponges. Other studies have found a high degree of variability in strategies employed by individuals within a species (Swearingen \& Pawlik 1998), among different populations of a given species (Assmann et al. 2000), and among closely related species (Pawlik et al. 1995). The effectiveness of defenses will also vary with the species of predator. While some defensive properties may be effective against a number of different predators (e.g. Kubanek et al. 2002), no defense is ubiquitously effective, and there are many potential explanations for the variability observed in feeding studies. Structural and chemical defenses can co-occur (Puglisi et al. 2000, 2002), and trade-offs have been identified in the role that sclerites play in structure and defense (West 1998). Bloom (1981) related skeletal features of 4 species of sponge to defense against predation by sponge-eating dorid nudibranchs. While his focus was on how nudibranchs partitioned the sponge resource, he identified morphological strategies that were effective against some (but not all) predators under specific ecological conditions. Chemical compounds are also apt to be influenced by these trade-offs and constraints.
There are several exciting developments in our understanding of the ecological significance of antipredator defenses in sponges. First, while early studies seemed to indicate that investment in defense for sponges was inversely related to latitude (e.g. Bakus \& Green 1974), recent work counters this hypothesis (e.g. McClintock 1987, Amsler et al. 2001, Becerro et al. 2003). Second, exploration of how structural and chemical materials interact to influence sponge defensive characteristics is just beginning, and there are indications that they may play an important role in sponge defenses (Burns \& Ilan 2003). Third, recent work (e.g. Burns \& Ilan 2003) indicates that sponge structural defenses are effective in a species-specific manner, which contradicts previous findings that skeletal material is generally ineffective at defense. It is clear that several important questions concerning sponge anti-predator defense remain and that our understanding of sponge defenses is evolving.

Acknowledgements. We thank A. Hill, J. Klug and T. Osier for comments and suggestions they provided throughout this research. J. Pawlik and 3 anonymous reviewers provided valuable suggestions. L. McSweeney provided statistical advice. M. Kubasik and L. K. Steffen provided equipment, advice and assistance during extraction of chemicals from sponges. This work was supported in part by grants from the Council on Undergraduate Research (to N.A.L.), and Merck/AAAS and Sigma Xi Grants-in-Aid of Research (to K.A.Y.). Funds were also provided by Fairfield University.

\section{LITERATURE CITED}

Amsler CD, McClintock JB, Baker BJ (2000) Chemical defenses of Antarctic marine organisms: a re-evaluation of the latitudinal hypothesis. In: Davidson W, HowardWilliams C, Broadey P (eds) Antarctic ecosystems: models for wider ecological understanding. Proc 7th SCAR International Biology Symposium. NZ Natural Science, Christchurch, p 158-164

Amsler CD, McClintock JB, Baker BJ (2001) Secondary metabolites as mediators of trophic interactions among Antarctic marine organisms. Am Zool 41:17-26

Assmann M, Lichte E, Pawlik JR, Köck M (2000) Chemical defenses of the Caribbean sponges Agelas wiedenmayeri and Agelas conifera. Mar Ecol Prog Ser 207:255-262

Bakus GJ (1964) The effects of fish-grazing on invertebrate evolution in shallow tropical waters. Occ Pap Allan Hancock Found 27:1-29

Bakus GJ, Green G (1974) Toxicity in sponges and holothurians: a geographic pattern. Science 185:951-953

Becerro MA, Paul VJ, Starmer J (1998) Intracolonial variation in chemical defenses of the sponge Cacospongia sp. and its consequences on generalist fish predators and the specialist nudibranch predator Glossodoris pallida. Mar Ecol Prog Ser 168:187-196

Becerro MA, Thacker RW, Turon X, Uriz MJ, Paul VJ (2003) Biogeography of sponge chemical ecology: comparisons of tropical and temperate defenses. Oecologia 135:91-101

Bloom SA (1975) The motile escape response of a sessile prey: a sponge-scallop mutualism. J Exp Mar Biol Ecol 17: $311-321$ 
Bloom SA (1976) Morphological correlations between dorid nudibranch predators and sponge prey. Veliger 18:289-301

Bloom SA (1981) Specialization and noncompetitive resource partitioning among sponge-eating dorid nudibranchs. Oecologia 49:305-315

Burns E, Ilan M (2003) Comparison of anti-predatory defenses of Red Sea and Caribbean sponges. II. Physical defense. Mar Ecol Prog Ser 252:115-123

Chanas B, Pawlik JR (1995) Defenses of Caribbean sponges against predatory reef fish. II. Spicules, tissue toughness, and nutritional quality. Mar Ecol Prog Ser 127:195-211

Chanas B, Pawlik JR (1996) Does the skeleton of a sponge provide defense against predatory reef fish? Oecologia 107:225-231

Dayton PK, Robilliard GA, Paine RT, Dayton LB (1974) Biological accommodation in the benthic community at McMurdo Sound, Antarctica. Ecol Monogr 44:105-128

Duckworth AR (2003) Effect of wound size on the growth and regeneration of two temperate subtidal sponges. J Exp Mar Biol Ecol 287:139-153

Dunlap M, Pawlik JR (1996) Video-monitored predation by Caribbean reef fishes on an array of mangrove and reef sponges. Mar Biol 126:117-123

Furrow FB, Amsler CD, McClintock JB, Baker BJ (2003) Surface sequestration of chemical feeding deterrents in the Antarctic sponge Latrunculia aplicalis as an optimal defense against sea star spongivory. Mar Biol 143:443-449

Guida VG (1976) Sponge predation in the oyster reef community as demonstrated with Cliona celata Grant. J Exp Mar Biol Ecol 25:109-122

Hartman WD (1958) Natural history of the marine sponges of southern New England. Peabody Mus Nat Hist Bull 12: $1-155$

Hay ME (1996) Defensive synergisms? Reply to Pennings. Ecology 77:1950-1952

Hay ME, Kappel QE, Fenical W (1994) Synergisms in plant defenses against herbivores: interactions of chemistry, calcification, and plant quality. Ecology 75:1714-1726

Hill MS (1998) Spongivory on Caribbean reefs releases corals from competition with sponges. Oecologia 117:143-150

Hill MS (1999) Morphological and genetic examination of phenotypic variability in the tropical sponge Anthosigmella varians. In: Hopper JNA (ed) Proceedings of the 5th International Sponge Symposium, Origin and Outlook. Mem Queensl Mus 44:239-248

Hill MS, Hill AL (2002) Morphological plasticity in the tropical sponge Anthosigmella varians: responses to predators and wave energy. Biol Bull (Woods Hole) 202:86-95

Hourigan TF, Stanton FG, Motta PJ, Kelly CD, Carlson B (1989) The feeding ecology of three species of Caribbean angelfishes (family Pomacanthidae). Environ Biol Fish 24: 105-116

Kelly-Borges M, Pomponi S (1992) The simple fool's guide to sponge taxonomy. Harbor Branch Oceanographic Institution, Fort Pierce, FL

Kubanek J, Whalen KE, Engel S, Kelly SR, Henkel TP, Fenical W, Pawlik JR (2002) Multiple defensive roles for triterpene glycosides from two Caribbean sponges. Oecologia 131: 125-136

Leon YM, Bjorndal KA (2002) Selective feeding in the hawksbill turtle, an important predator in coral reef ecosystems. Mar Ecol Prog Ser 245:249-258

McClintock JB (1987) Investigation of the relationship between invertebrate predation and biochemical composition, energy content, spicule armament and toxicity of benthic sponges at McMurdo Sound, Antarctica. Mar Biol 94:479-487
McClintock JB, Baker BJ (2001) Marine chemical ecology. CRC Press, Boca Raton, FL

Meylan A (1988) Spongivory in hawksbill turtles: a diet of glass. Science 239:393-395

Paul VJ (1992) Ecological roles of marine natural products. Cornell University Press, Ithaca, NY

Pawlik JR (1993) Marine invertebrate chemical defenses. Chem Rev 93:1911-1922

Pawlik JR (1997) Fish predation on Caribbean reef sponges: an emerging perspective of chemical defenses. Proc 8th Int Coral Reef Sym 2:1255-1258

Pawlik JR (1998) Coral reef sponges: do predatory fishes affect their distributions? Limnol Oceanogr 43:1396-1399

Pawlik JR, Chanas B, Toonen RJ, Fenical W (1995) Defenses of Caribbean sponges against predatory reef fish. I. Chemical deterrency. Mar Ecol Prog Ser 127:183-194

Pennings SC (1996) Testing for synergisms between chemical and mineral defenses-a comment. Ecology 77: 1948-1950

Pennings SC, Pablo SR, Paul VJ, Duffy E (1994) Effects of sponge secondary metabolites in different diets on feeding by three groups of consumers. J Exp Mar Biol Ecol 180: 137-149

Pennings SC, Carefoot TH, Siska EL, Chase ME, Page TA (1998) Feeding preferences of a generalist salt-marsh crab: relative importance of multiple plant traits. Ecology 79:1968-1979

Puglisi MP, Paul VJ, Slattery M (2000) Biogeographic comparisons of chemical and structural defenses of the Pacific gorgonians Annella mollis and A. reticulata. Mar Ecol Prog Ser 207:263-272

Puglisi MP, Paul VJ, Biggs J, Slattery M (2002) The co-occurrence of chemical and structural defenses in gorgonian corals of Guam. Mar Ecol Prog Ser 239:105-114

Randall JE, Hartman WD (1968) Sponge-feeding fishes of the West Indies. Mar Biol 1:216-225

Swearingen DC, Pawlik JR (1998) Variability in the chemical defense of the sponge Chondrilla nucula against predatory reef fishes. Mar Biol 131:619-627

Targett NM, Schmahl GP (1984) Chemical ecology and distribution of sponges in the Salt River Canyon, USVI. NOAA Tech Mem OAR NURP-1, Rockville, MD

Thompson TE, Brown GH (1984) Biology of opisthobranch mollusks, Vol 2. Ray Society 156:1-229

Turon X, Becerro MA, Uriz, MJ (1996) Seasonal patterns of toxicity in benthic invertebrates: the encrusting sponge Crambe crambe (Poecilosclerida). Oikos 75:33-40

Turon X, Tarjuelo I, Uriz MJ (1998) Growth dynamics and mortality of the encrusting sponge Crambe crambe (Poecilosclerida) in contrasting habitats: correlation with population structure and investment in defence. Funct Ecol 12: 631-639

Uriz MJ, Turon X, Becerro MA, Galera J (1996) Feeding deterrence in sponges: the role of toxicity, physical defenses, energetic contents, and life-history stage. J Exp Mar Biol Ecol 205:187-204

Waddell B, Pawlik JR (2000a) Defenses of Caribbean sponges against invertebrate predators. I. Assays with hermit crabs. Mar Ecol Prog Ser 195:125-132

Waddell B, Pawlik JR (2000b) Defenses of Caribbean sponges against invertebrate predators. II. Assays with sea stars. Mar Ecol Prog Ser 195:133-144

West JM (1998) The dual role of sclerites in a gorgonian coral: conflicting functions of support and defence. Evol Ecol 12: 803-821

Wieczorek SK, Hooper RG (1995) Relationship between diet and food availability in the snow crab Chionoecetes opilio 
(O. Fabricius) in Bonne Bay, Newfoundland. J Crustac Biol 15:236-247

Wulff JL (1994) Sponge-feeding by Caribbean angelfishes, trunkfishes and filefishes. In: Van Soest RWM, van Kempen TMG, Braekman JC (eds) Sponges in time and space: biology, chemistry, paleontology. AA Balkema, Rotterdam, p 265-271

Editorial responsibility: Joseph Pawlik (Contributing Editor), Wilmington, North Carolina, USA
Wulff JL (1995) Sponge-feeding by Caribbean starfish Oreaster reticulatus. Mar Biol 123:313-325

Wulff JL (2000) Sponge predators may determine differences in sponge fauna between two sets of Mangrove Cays, Belize Barrier Reef. Atoll Res Bull 477:251-263

Zar JH (1984) Biostatistical analysis, 2nd edn. Prentice Hall, Englewood Cliffs, NJ

Submitted: October 10, 2004; Accepted: December 10, 2004 Proofs received from author(s): April 5, 2005 